University of Wollongong

Research Online

Faculty of Commerce - Papers (Archive)

Faculty of Business and Law

$1-1-2010$

\title{
An empirical analysis of the retention of dissatisfied business services customers using structural equation modelling
}

Venkata K. Yanamandram

University of Wollongong, venkaty@uow.edu.au

Lesley White

University of Sydney

Follow this and additional works at: https://ro.uow.edu.au/commpapers

Part of the Business Commons, and the Social and Behavioral Sciences Commons

\section{Recommended Citation}

Yanamandram, Venkata K. and White, Lesley: An empirical analysis of the retention of dissatisfied business services customers using structural equation modelling 2010, 222-232.

https://ro.uow.edu.au/commpapers/781

Research Online is the open access institutional repository for the University of Wollongong. For further information contact the UOW Library: research-pubs@uow.edu.au 


\title{
An empirical analysis of the retention of dissatisfied business services customers using structural equation modelling
}

\author{
Abstract \\ This study extends the body of literature concerning service switching, complaint handling, dependence \\ and commitment by investigating why dissatisfied B2B customers do not switch service providers. \\ Specifically, it develops and tests a social exchange-based model examining how dissatisfied, but \\ behaviourally loyal, customers act in terms of their repurchase intentions. A conceptual model, specifying \\ a set of hypothesised relationships between dimensions of switching costs, interpersonal relationships, \\ dimensions of complaint handling, satisfaction with complaint handling, attractiveness of alternatives, \\ dependence, calculative commitment and repurchase intentions, was examined using AMOS 17.0 on a \\ sample of 376 business directors/managers from responding organisations. The results show that \\ satisfaction with complaint handling, benefit-loss costs, dependence and calculative commitment \\ significantly increase customers' repurchase intentions. The findings also indicate that dependence, \\ interpersonal relationships and specific types of switching costs influence customers' calculative \\ commitment, and the latter influences intentions to repurchase services. The study builds on the \\ Investment Model by including justice components, and examines the effects of different types of \\ antecedents on calculative commitment that have previously not been examined.

\section{Keywords} \\ empirical, services, analysis, customers, structural, equation, modelling, retention, dissatisfied, business

\section{Disciplines} \\ Business | Social and Behavioral Sciences

\section{Publication Details} \\ Yanamandram, V. K. \& White, L. (2010). An empirical analysis of the retention of dissatisfied business \\ services customers using structural equation modelling. Australasian Marketing Journal, 18 (4), 222-232.
}




\title{
An Empirical Analysis of the Retention of Dissatisfied Business Services Customers using Structural Equation Modelling
}

\begin{abstract}
This study extends the body of literature concerning service switching, complaint handling, dependence and commitment by investigating why dissatisfied B2B customers do not switch service providers. Specifically, it develops and tests a social exchange-based model examining how dissatisfied, but behaviourally loyal, customers act in terms of their repurchase intentions. A conceptual model, specifying a set of hypothesised relationships between dimensions of switching costs, interpersonal relationships, dimensions of complaint handling, satisfaction with complaint handling, attractiveness of alternatives, dependence, calculative commitment and repurchase intentions, was examined using AMOS 17.0 on a sample of 376 business directors/managers from responding organisations. The results show that satisfaction with complaint handling, benefit-loss costs, dependence and calculative commitment significantly increase customers' repurchase intentions. The findings also indicate that dependence, interpersonal relationships and specific types of switching costs influence customers' calculative commitment, and the latter influences intentions to repurchase services. The study builds on the Investment Model by including justice components, and examines the effects of different types of antecedents on calculative commitment that have previously not been examined.
\end{abstract}

Keywords: Dissatisfied customers, Business services, Customer retention, Dependence, Calculative commitment, Social exchange 


\section{Introduction}

The benefits to service providers of customer retention can be significant. However, service practitioners are increasingly concerned about the retention of customers because of customer switching behaviour. For example, Teradata reports that $79 \%$ of bank executives indicate that preventing customer defection is a key competitive issue (Sweeney and Swait, 2008) - an understandable concern, because defecting customers adversely affect market share, profits and future revenues (Reichheld and Sasser, 1990).

The strategic importance of customer retention and the costs associated with customer switching behaviour mean that researchers have focused on investigating the switching and/or staying behaviour of customers in the business-to-consumer (B2C) services sector, specifically: (1) processes or behaviours associated with relationship switching (e.g. Keaveney, 1995; Roos et al., 2004; Tuominen and Kettunen, 2003); (2) what influences switching behaviour (e.g. Bansal et al., 2004); (3) differences between switchers and stayers (e.g. Ganesh et al., 2000); and (4) what encourages people to remain in relationships by deterring them from leaving (e.g. Burnham et al., 2003; Colgate et al., 2007; Jones et al., 2007; Patterson, 2004; Patterson and Smith, 2003).

Although previous research provides a foundation for understanding the development, defection and maintenance of sound relationships, only limited work exists on the continuation of troubled business-to-business (B2B) relationships (Colgate and Norris, 2001; Tahtinen and Vaaland, 2006). Scholars note that future research should examine reasons for staying after a switching dilemma in a B2B services context (Colgate et al., 2007) and should also explore the impact of dissatisfaction on the effects of buyer entrapment in a business service context (Liu, 2006). This paper addresses these gaps in existing research by examining why dissatisfied customers do not switch service providers. Specifically, the paper develops and tests a social exchange-based model examining how dissatisfied, but behaviourally loyal, customers act in terms of their repurchase intentions. The paper extends the body of literature concerning service switching, complaint handling, dependence and commitment, and focuses on an important but neglected area, B2B services. 


\section{Theoretical framework}

The investment model of personal relationships (Rusbult et al., 1998) extends interdependence theory propositions to analyse the tendency to persist in a relationship, and accounts for dependence and commitment development in two respects. First, the model asserts that satisfaction, quality of alternatives and investment size influence dependence. Second, the model suggests that commitment emerges as a consequence of increasing dependence. However, the model does not explicitly consider justice in the achievement of satisfaction; rather, satisfaction in a relationship is achieved when the relationship provides high rewards and low costs. The inclusion of justice in the current research is critical, because customers expect fair resolutions to service failures and complaints (Goodwin and Ross, 1992). For a detailed review of the theoretical framework, see Yanamandram and White (in press).

\section{Research model and hypotheses ${ }^{1}$}

\section{Insert Figure 1 about here}

\subsection{Repurchase intentions}

Repurchase intentions is the dependent variable in Figure 1. Repurchase intentions represent a customer's judgment about again buying a designated service from the same service provider, considering the customer's current situation (Hellier et al., 2003). In this current study, repurchase intentions indicate the degree that people are willing or reluctant to purchase and how much effort they will exert during purchasing (Ajzen, 1991).

\section{2. $\quad$ Effects on satisfaction with complaint handling}

Service failures comprise instances of conflict situations and the justice theory explains customers' reactions to conflict situations (Goodwin and Ross, 1992). The literature identifies three dimensions of perceived justice: (1) Distributive justice describes a customer's perception of fairness in the complaint outcome and includes whether the outcomes are perceived as

\footnotetext{
${ }^{1}$ It is entirely possible for a customer to be in an overall sense dissatisfied, and yet satisfied with specific incidents. For example, a qualitative study (Yanamandram and White, 2006) indicated that customers were dissatisfied overall, because of forced dependent relations and negative emotional attachment caused by cost/benefit reasoning where the costs outweighed the benefits, although they tend to be satisfied with the outcome and process of complaints.
} 
deserved, meeting their needs or fair (Tax et al., 1998); (2) Procedural justice refers to the perceived fairness associated with the decision-making procedures used to rectify a problem (Tax et al., 1998), and includes how quickly a conflict is resolved (Blodgett et al., 1997); and (3) Interactional justice refers to the perceived fairness of the interpersonal treatment received during enacting procedures and delivering outcomes (Tax et al., 1998) and includes the employee empathy, employee politeness and employee effort (Homburg and Furst, 2005).

Satisfaction with complaint handling is a key variable that links perceptions of the justice dimensions to post-complaint attitudes and behaviours (Tax et al., 1998). Satisfaction with complaint handling refers to the customer's overall psychological response or feeling about the service provider's handling of the service problems. Maxham and Netemeyer (2002) contend that if a customer perceives outcomes as fair, deems the process where outcomes were provided as fair, and recognises that they have been treated fairly in their personal interactions with their service provider throughout the complaint handling process, then the customer should be satisfied with the complaint handling process. Hoffman and Kelley (2000) argue that theoretically, when service failures occur and switching costs are high, switching to another service provider is minimal, provided the service recovery strategy resolves the customer's problem. Building on the above-cited theoretical and empirical foundations, we hypothesise that:

$\mathbf{H}_{1 \mathbf{a}}$ : As perceptions of distributive justice increase, satisfaction with complaint handling increases.

$\mathbf{H}_{1 \mathbf{b}}$ : As perceptions of procedural justice increase, satisfaction with complaint handling increases.

$\mathbf{H}_{1 \mathbf{c}}$ : As perceptions of interactional justice increase, satisfaction with complaint handling increases. 


\subsection{Effects on calculative commitment ${ }^{2}$}

Calculative commitment is "the state of attachment to a partner cognitively experienced as a realisation of the benefits sacrificed and losses incurred if the relationship were to end" (Gilliland and Bello, 2002, p. 28). The limited empirical studies that investigate the antecedents of calculative commitment either study: (1) only one antecedent in a B2C services context (procedural switching costs, Jones et al., 2007) or in a B2B services context (switching costs, Venetis and Ghauri, 2004); or (2) only a few antecedents, either in a B2C services context (switching costs and alternative attractiveness, Bansal et al., 2004) or in a B2B goods context (switching costs and alternative attractiveness, Ping, 1997). Based on Gilliland and Bello (2002), this current research proposes three antecedents of calculative commitment: dependence, investments and attractiveness of alternatives.

Dependence refers to the extent to which a customer firm needs the service provider to achieve its goals (Frazier, 1983). A non-voluntary dependence that is forced through circumstances may still lead to a commitment without an affective component (Iacobucci and Ostrom, 1996). A customer who perceives the service provider as crucial to their future performance is likely to develop a cognitive attachment to avoid potential losses and hardship associated with terminating the relationship; thereby committing to the relationship. These contentions regarding dependence-based commitment have empirical support in a B2B goods context (Gilliland and Bello, 2002; Wetzels et al., 1998); however, no studies exist in a B2B services context. Therefore, we hypothesise that:

$\mathbf{H}_{2}$ : As perceptions of dependence increase, calculative commitment increases.

\footnotetext{
${ }^{2}$ The decision to use only calculative commitment (and not affective commitment) is based on the rationale that business customers who are dissatisfied are not likely to show affective commitment. The Commitment Framework (Johnson, 1991) holds that high levels of personal (affective) commitment may mitigate the impact of structural (calculative) commitment on partners. When low levels of affective (and moral) commitments are present, the effect of structural commitment will become more prominent and will contribute to a sense of being entrapped in the relationship. Consequently, a partner will feel constrained by the costs of dissolution to stay. In the marketing literature, Ping (1999) argued that in 'have to' relationships, "the subject's attitudinal commitment may no longer exist" (p.236), yet the subject stays in the relationship because of structural commitment. Indeed, research has shown that an increase in calculative commitment has the strongest positive influence under conditions of low affective commitment (Fullerton, 2003; Jones et al., 2007). Therefore, affective commitment was not used in this study.
} 
Becker (1960) argues that side-bet investments (such as time, money or effort) operate to create penalties (such as loss or devaluation of investments), and ultimately compel people to commit to certain behaviours. Because investments lose value if the relationship fails, the customer calculates the implications of leaving, and a rational attachment to the service provider emerges to support its existing stake (Gilliland and Bello, 2002).

There is evidence of relationship-specific investments at both inter-organisational level and interpersonal levels - usually termed switching costs and interpersonal relationships respectively (Wathne et al., 2001). Switching costs arise from organisational-level investments in transaction-specific assets (Wathne et al., 2001); interpersonal relationships derive from an individual's investment in social capital (Wathne et al., 2001).

Switching costs refer to the perceived economic and psychological costs associated with the process of switching from one service provider to another (Heide and Weiss, 1995). Based on Burnham et al. (2003) and Jones et al. (2002), switching costs in this current research model indicate: (1) benefit-loss costs that represent the possible loss of economic benefits when a customer leaves their existing service provider and switches to a new service provider, (2) economic-risk costs that refer to the psychological uncertainty or perceptions of risk surrounding the performance when a customer with insufficient information adopts a new service provider, (3) evaluation costs that represent the time and effort costs associated with the search and analysis of potential alternate service providers prior to switching, (4) learning costs that represent the time and effort costs associated with learning and adapting to new procedures and routines in order to use a service effectively and (5) sunk costs that represent the nonrecoupable time and effort invested in establishing and maintaining an exchange relationship.

Regarding the type of switching costs that would lead to calculative commitment, Jones et al. (2007) argue that procedural switching costs derived from negative sources of constraint escalate perceptions of calculative commitment. They explain that because social switching costs and benefit-loss costs derive primarily from positive sources of constraint because they represent positive benefits and value, and because calculative commitment is rooted in relatively negative aspects of a relationship because it reflects a customer's feeling that they 'have to' stay, they propose only a relationship between procedural switching costs and calculative commitment. However, calculative commitment represents a cognitive commitment that is experienced as an understanding of the sacrifices associated with termination, including lost current and future benefits from existing customers; the disruption and difficulty of moving to another service provider; and the loss of sunk idiosyncratic investments (Gilliland and Bello, 2002). These contentions suggest that the different types of procedural switching 
costs drive up perceptions of calculative commitment, such as: (1) time-and-effort costs associated with the search and analysis of potential alternate service providers before switching (evaluation costs); (2) time-and-effort costs associated with learning and adapting to new procedures and routines in order to use a service effectively (learning costs); and (3) perceptions of risk surrounding the performance of an unknown service provider (economic risk costs); but so do: (4) benefit-loss costs; and (5) sunk-costs. Therefore, the following hypotheses are advanced:

$\mathbf{H}_{3 \mathbf{a}}$ : As perceptions of benefit-loss costs increase, calculative commitment increases.

$\mathbf{H}_{3 \mathbf{b} \text { : }}$ As perceptions of economic-risk costs increase, calculative commitment increases.

$\mathbf{H}_{3 \mathbf{3} \text { : }}$ As perceptions of evaluation costs increase, calculative commitment increases.

$\mathbf{H}_{3 \mathbf{3 d}}$ As perceptions of learning costs increase, calculative commitment increases.

$\mathbf{H}_{3 \mathrm{e}}$ : As perceptions of sunk costs increase, calculative commitment increases.

Interpersonal relationships refer to the level of personal and social relationships between boundary-spanning personnel in the transacting organisations, and subsume aspects of friendship, familiarity and rapport (Price and Arnould, 1999; Wathne et al., 2001). While research generally shows that customers and suppliers bound by strong personal relationships are committed to maintain relationships (Wilson and Mummalaneni, 1986), a company can rarely justify bad decisions based on friendship alone between boundary-spanning personnel (Gounaris, 2005). Wetzels et al. (1998) argue that partners bound by strong relationships are more likely to be emotionally involved and less likely to consciously weigh the benefits against the costs of that relationship. Thus, social bonds could negatively influence calculative commitment. Based on this discussion, the following hypothesis is proposed:

$\mathbf{H}_{4}$ : As perceptions of interpersonal relationships increase, calculative commitment decreases.

Attractiveness of alternative service providers refers to customer perceptions regarding the extent to which viable competing alternatives are available in the marketplace. Bansal et al. (2004) posits: "to the extent that alternative service providers are perceived to be attractive, consumers are less likely to feel 'locked-in' to their current service providers" (p. 238), and hypothesises that the stronger the alternative attractiveness, the weaker the continuance commitment to the service provider - but found no support for their hypothesis. Conversely, 
Huang et al. (2007) found support for their hypothesis that the attractiveness of online brokerage users' alternatives is negatively associated with continuance commitment. Albeit the mixed results in a B2C context, our research model concurs with Johnson's (1991) tripartite model of commitment, which argues that structural commitment - a feeling that one must remain in the relationship - results from the relative unattractiveness of alternatives. Therefore, we hypothesise that:

H5: As perceptions of attractiveness of alternative service providers increase, calculative commitment decreases.

\subsection{Effects on repurchase intentions}

Most dissatisfied customers will do business with the firm again if their problems are solved satisfactorily; however, empirical studies show mixed results in a B2C context (Homburg and Furst, 2005; Maxham and Netemeyer, 2002). In a qualitative study of business banking customers, Colgate and Norris (2001) found that some customers stayed with their service provider regardless of satisfaction with the recovery efforts because of the perception of high exit barriers. Thus, a customer who is dissatisfied overall with the relationship, and has considered switching, may intend to repurchase - even if they are minimally satisfied with the complaint handling. Therefore,

$\mathbf{H}_{6}$ : As perceptions of satisfaction with complaint handling increase, repurchase intentions increase.

Drigotas and Rusbult (1992) assert that a dissatisfactory relationship may nevertheless fulfil important needs that cannot be fulfilled in alternative relationships. Thus, a firm will maintain a relationship with a supplier if dependence (goals realised only from a given relationship) is higher (Frazier, 1983). Using an experiment involving purchasing agents as participants in an electronic equipment setting, Joshi and Arnold (1998) found that relationships between dependence and intention to continue were significant. Thus, based on the contention by Drigotas and Rusbult (1992), a dissatisfied customer may intend to repurchase services if the company fulfils needs which may not be obtained in alternative relationships. Therefore:

$\mathbf{H}_{7}$ : As perceptions of dependence increase, repurchase intentions increase. 
A partner who forms a cognitive attachment, albeit dispassionately, after realising the benefits which would be sacrificed and the losses incurred should the relationship end, is unlikely to leave a relationship (Gilliland and Bello, 2002). Moorman et al. (1992) suggest that buyers committed to a relationship might be more predisposed to act because they need commitment consistency. In a B2B goods context, Wetzels et al. (1998) found a positive relationship between calculative commitment and intention to stay. However, in a B2B services context, none of the studies, namely, Venetis and Ghauri (2004), Gounaris (2005) and Rauyruen and Miller (2007) found a significant relationship between calculative commitment and repurchase intentions. In Venetis and Ghauri's (2004) study of customers in the advertising sector, calculative commitment did not significantly influence repurchase intentions, despite being significantly correlated with stay intention, because affective commitment was found to be a stronger motivation for customers to stay in the relationship. In Gounaris's (2005) study of customers using training and recruitment services, calculative commitment had a nonsignificant and a negative relationship with intention to stay. Gounaris (2005) reasoned that customers may have felt aggravated to seek escape from a feeling of being dependent, thus resulting in behaviour that is directed toward self gains. Rauyruen and Miller's (2007) study of customers using courier delivery services found that neither affective nor calculative commitment was significant in influencing repurchase intentions, and that other factors (such as customer satisfaction and perception of service quality) significantly influenced customers' intentions to purchase. Additionally, the services investigated in both Gouraris (2005) and Rauyruen and Miller (2007) are relatively simple. In complex services, the outcomes could be different. Although dissatisfied, complaining customers may consider switching, calculative committed customers are likely to continue a relationship if they contend that the costs associated with leaving a service provider are higher than the expected benefits of switching (de Ruyter et al., 2001). Therefore,

$\mathbf{H}_{8}$ : As perceptions of calculative commitment increase, repurchase intentions increase.

The literature points to a significant association between switching costs and switching intentions or repurchase intentions/loyalty, in a B2B context (Lam et al., 2004; Liu et al., 2005; Wathne et al., 2001). Within switching costs, benefit-loss costs have a strong impact on behavioural intentions, although the relationship between benefit-loss costs and repurchase 
intentions has only been investigated in a B2C services context (Jones et al., 2002; Patterson and Smith, 2003). Benefit-loss costs derive from service benefits accrued from a given service provider over time (Jones et al., 2002). Therefore, these costs should be strongly associated with repurchase intentions.

H9: As perceptions of benefit-loss costs increase, repurchase intentions increase.

\section{Research design and methodology \\ 4.1 Data collection procedure and sample}

The research collection instrument used for this study was a self-administered, email URL-embedded online questionnaire. Whilst there is evidence that both online and mail surveys produce equivalent results on the basis of accuracy and completeness of respondent answers to both open and closed questions, online surveys have additional advantages of producing faster responses and lower costs (Deutskens et al., 2006). For this reason, the use of an online survey approach was considered appropriate in our research.

A pre-recruited internet market research panel was used to compile a sample for this study. The sampling frame consisted of a database of business managers, who were screened for eligibility. The sample represented small, medium and large businesses. Discussion with the selected market research firm revealed that approximately $40 \%$ of those receiving emails from the sample frame typically qualify, and $60 \%$ of those who qualify respond. Subsequently, we decided to send approximately 2,000 emails initially, and then use the responses obtained to determine if additional waves were necessary. Ultimately, we distributed 2,083 emails in a single wave to prospective participants from the sampling frame. We received all responses in the first two days of survey administration, with over $80 \%$ of responses received within the first 24 hours of sending the email.

\subsection{Unit of analysis and sample characteristics}

The unit of analysis selected was the company. Survey respondents reported their perceptions and judgments at the organisational unit of analysis. Participants who did not meet both of the following criteria were screened out: Firstly, the informant or the firm they work for had to be currently dissatisfied with any aspect of the service provided to the organisation by any of their current service providers, and secondly that for the service that their 
organisation was currently dissatisfied with, the informant was or has been making decisions regarding the purchase of the service.

Ultimately, a single key informant approach was deemed to be an acceptable choice for two reasons: (1) it enables respondents to remain anonymous and does not necessitate their disclosing the names of other buying centre members, thus encouraging candid responses (Kohli, 1989). This was an important consideration, given the potentially sensitive nature of the study, and (2) it is appropriate where the informant occupies a senior or ownership position (Pennings, 1979). Our data revealed that a sizeable portion of the key informants were owners or managing directors of the customer firm (32\%), followed by operations directors (19\%), IT directors (15\%), marketing/sales/customer-service directors (11\%), finance directors (11\%) and purchasing directors $(6 \%)$. Only six per cent of the key informants' positions were as specialist managers.

To increase the validity and reliability of the data collected, three criteria post hoc were employed to assess the informants' appropriateness: (1) informant's personal knowledge on decisions relating to the purchase of the service for their company (Campbell, 1955), (2) informant's extent of participation in influencing, deciding or purchasing the service for their company (Phillips 1981), and (3) the extent to which the views of the informant were representative of the views of the group responsible for buying the service described in the survey (Patterson et al., 1997). The decision rules closely mirrored the procedures followed by Rokkan et al. (2003), Phillips (1981) and Patterson et al. (1997) respectively. A post hoc decision was also made to exclude informants who reported that their organisation did not (a) complain and (b) consider switching ${ }^{3}$. The use of three key informant criteria and complaining and switching consideration produced a final sample size of 376 cases.

Key informants discussed a range of services representing a variety of industries. Four types of services accounted for just over $80 \%$ of the services chosen by the key informants to describe in the survey: information technology services (35\%), banking services (29\%), facility services (10\%), and professional services (7\%). Responding organisations represented a variety of industries. Most key informants $(91 \%)$ participated at least half the time in influencing,

\footnotetext{
${ }^{3}$ There is evidence in the literature that B2B customers regularly confront service providers with complaints (eg., Homburg and Furst, 2005). Only key informants who had complained were included in this study, because complaining indicates an "active" and "constructive" response to dissatisfaction, with the intent of improving conditions (Rusbult, Zembrodt and Gunn, 1982, p.1231). Similarly, only key informants who had considered switching, but ultimately decided to stay with their service provider were included in this study, because they impart "insight into true behaviour rather than predicted behaviour" (Colgate et al., 2007, p. 211).
} 
deciding or purchasing the chosen service for their company. The mean knowledge score for key informants on decisions relating to purchase of the chosen service for their company was 5.9 (on a seven-point scale; SD $=0.9$ ). Finally, most key informants $(94 \%)$ felt that the views they expressed in the survey were representative of the views of the group responsible for buying the chosen service. Overall, the mean response to representativeness of views was 5.5 (on the seven-point scale; $\mathrm{SD}=1.2$ ). Key informants reported moderate to high overall dissatisfaction (mean $=4.7$ on a seven-point scale anchored by "dissatisfaction is extremely low" and "dissatisfaction is extremely high;" SD =1.3). Key informants rated the severity of the service problems they faced as significant (mean $=5.0$ on a seven-point scale; $\mathrm{SD}=1.1$ ).

\subsection{Measures}

We derived the measurement instruments in the survey from pre-existing scales from consumer research, and made minor adjustments to the wording of items to make sense to respondents in the present context. Previous research in a B2B services context indicates that consumer scales can be successfully transferred into business context (Bennett, 2001). Five key informants who participated earlier in a qualitative phase of this research project, evaluated the items and full questionnaire before the survey was placed on the internet. All items used sevenpoint Likert-type scale responses, except satisfaction with complaint handling (see Table 1). Our measures were purified through a process that examined the standardised factor loadings, as well as the squared multiple correlations $\left(\mathrm{R}^{2}\right)$ between the items and latent constructs, with factor loadings of .70 and $\mathrm{R}^{2}$ values above .50 used as criteria (Bollen, 1989). We also examined the unidimensionality of items by means of a series of confirmatory factor models (Gerbing and Anderson, 1988). We removed items that did not meet the criteria from further analysis. These procedures resulted in two of the benefit-loss costs items and one item each from the remainder of the constructs being deleted. The sources of scale items used in this current study are summarised in Table 1.

\subsection{Model estimation}

The data were analysed following Anderson and Gerbing's (1988) two-step approach: a measurement model and a subsequent structural model. Both the measurement and structural models were estimated using AMOS 17.0 with maximum likelihood (ML) estimation. A confirmatory factor analysis (CFA) determined the fit of the measurement model. The adequacy of the individual items was assessed by construct reliability, convergent validity and discriminant validity. After measure validation, structural equation modelling (SEM) was used 
to test the validity of the research model and the hypotheses. The structural model was specified using the same measurement structure that is represented in the measurement model.

\section{Results}

Given the known sensitivity of the $\chi^{2}$ statistics test to sample size, several widely used goodness-of-fit indices demonstrated that the confirmatory factor model fit the data well $\left(\chi^{2}=\right.$ $1019.63 ; \mathrm{df}=611 ; \mathrm{p}=.00 ; \chi^{2} / \mathrm{df}=1.67 ; \mathrm{CFI}=.96 ; \mathrm{TLI}=.96 ; \mathrm{GFI}=.88 ; \mathrm{NFI}=.91 ; \mathrm{IFI}=.96 ;$ RMSEA $=.04 ;$ SRMR $=.03)$. The construct reliability for all the measures exceeded the advocated threshold of .70, and the variance extracted for all the factors exceeded the rigorous level of .50 (Table 1). Convergent validity was satisfied in that all confirmatory factor loadings exceeded .76 and were significant at .01 (Anderson and Gerbing, 1988). Discriminant validity was tested by comparing the average variance extracted (AVE) with the squared correlation between constructs (Fornell and Larcker, 1981). The AVEs were greater than the squared correlations between any pair of constructs, meaning they exhibit discriminant validity. The bivariate correlations, means and standard deviations (SD) obtained from SPSS 17.0 are reported in Table 2.

Insert Table 1 about here

Insert Table 2 about here

As the next step, the proposed structural model was estimated (Table 3). The estimation produced the following statistics: $\chi^{2}=1068.81 ; \mathrm{df}=632 ; \mathrm{p}=.00 ; \chi^{2} / \mathrm{df}=1.69 ; \mathrm{CFI}=.96$; TLI $=.95 ; \mathrm{GFI}=.87 ; \mathrm{NFI}=.91 ; \mathrm{IFI}=.96 ; \mathrm{RMSEA}=.04 ;$ SRMR $=.04$. The model's fit as indicated by these indexes was deemed satisfactory; thus it provides a good basis for testing the hypothesised paths. Results indicated support for many of the hypotheses. The results fully supported the hypotheses on the effect of justice dimensions on satisfaction with complainthandling $\left(\mathrm{H}_{1 \mathrm{a}}, \mathrm{B}=.44, \mathrm{p}<.001 ; \mathrm{H}_{1 \mathrm{~b}}, \mathrm{~B}=.21, \mathrm{p}<.05 ; \mathrm{H}_{1 \mathrm{c}}, \mathrm{B}=.24 \mathrm{p}<.001\right)$. The hypotheses regarding the antecedents of calculative commitment received mixed support. Specifically, dependence $\left(\mathrm{H}_{2}, \beta=0.30, \mathrm{p}<.001\right)$, most dimensions of investments at the inter-organisational level $\left(\mathrm{H}_{3 \mathrm{a}}\right.$ benefit-loss costs, $\beta=0.18, \mathrm{p}<.01 ; \mathrm{H}_{3 \mathrm{c}}$ evaluation costs, $\beta=0.15, \mathrm{p}<.05 ; \mathrm{H}_{3 \mathrm{~d}}$ learning costs, $\beta=0.24, \mathrm{p}<.001 ; \mathrm{H}_{3 \mathrm{e}}$ sunk costs, $\left.\beta=0.25, \mathrm{p}<.001\right)$, and investment at the interpersonal level $\left(\mathrm{H}_{4}, \mathrm{~B}=-0.14, \mathrm{p}<.01\right)$ had significant effects on calculative commitment. In 
contrast, the hypotheses on the effects of economic-risk costs $\left(\mathrm{H}_{3 \mathrm{~b}}\right)$ and attractiveness of alternative service providers $\left(\mathrm{H}_{5}\right)$ were not supported. Finally, the hypothesis regarding the effects of satisfaction with complaint-handling on repurchase intentions $\left(\mathrm{H}_{6}, \beta=0.17, \mathrm{p}<.001\right)$, dependence on repurchase intentions $\left(\mathrm{H}_{7}, \beta=0.16, \mathrm{p}<.01\right)$, calculative commitment on repurchase intentions $\left(\mathrm{H}_{8}, \beta=0.20, \mathrm{p}<.001\right)$ and benefit-loss costs on repurchase intentions $\left(\mathrm{H}_{9}, \mathrm{~B}=0.34, \mathrm{p}<.001\right)$ were supported.

Insert Table 3 about here

\section{Discussion}

The findings generally lend support to the social exchange framework in a B2B services context by explaining the tendency to remain involved in a relationship. The model ${ }^{4}$ explained 38\% of variance in repurchase intentions, which is accounted for by its four predictors: benefit-loss costs, satisfaction with complaint-handling, dependence and calculative commitment. The model also explained $43 \%$ of variance in calculative commitment that is accounted for by its predictors, dependence, benefit-loss costs, evaluation costs, learning costs, sunk costs and interpersonal relationships.

The data analysis provides support for the hypotheses regarding the positive influence of justice dimensions on satisfaction with complaint-handling. The findings indicate that all the three dimensions of justice should be taken into consideration while evaluating any complainthandling efforts, because it is the combination of the dimensions of justice that determine the overall perceived justice and subsequent behavioural outcomes (Blodgett et al., 1997). This contention is substantiated by the evidence in this current study that the three dimensions of perceived justice accounted for $62 \%$ of the explained variance in satisfaction with complainthandling. Furthermore, satisfaction with complaint-handling has a direct and positive relationship with repurchase intentions.

The findings indicate that dependence and firm-level investments compel organisations to commit to continuing even a dissatisfactory relationship; however, the study offers varied results about the specific types of investments that lead to calculative commitment.

\footnotetext{
${ }^{4}$ The model of retention in this current study compares favourably to other models in the literature such as Wathne et al. (2001) that accounted for 35\% of the variance in supplier choice in a B2B context, and Bansal et al. (2004), whose customer commitment model accounted for $29 \%$ of the variance in switching intentions in a $\mathrm{B} 2 \mathrm{C}$ context.
} 
Specifically, the findings suggest that four factors result in buying firms developing a cognitive attachment to the service provider: (1) loss of benefits should the relationship end, (2) cognitive resources that are expended to gather information to evaluate the alternatives, (3) time-and-effort costs associated with learning and adapting to new procedures and routines in order to use a service effectively and (4) loss of idiosyncratic investments. These findings notwithstanding, the current research diverges from the contention of Jones et al. (2007): that only procedural switching costs (derived largely from negative sources of constraint) drive up perceptions of calculative commitment. The current findings indicate that evaluation and learning costs (facets of procedural switching costs) drive up perceptions of calculative commitment, but also that the loss of benefits as well as sunk costs drive up perceptions of calculative commitment.

The significant finding regarding the negative relationship between interpersonal relationships and calculative commitment supports the assertion in the literature that compared to structural bonds, social bonds are easier to break (Gounaris, 2005). The finding of this current study is however inconsistent with other research that concludes: (1) ties between boundary-spanners play a major role in maintaining inter-organisational relationships by reducing the likelihood of switching (Seabright et al., 1992) or developing commitment (Sweeney and Webb, 2007) and (2) strong interpersonal relationships positively influence customer's repurchase intentions in situations of low customer satisfaction (Jones et al., 2000). The current finding suggests that close personal relationships between boundary-spanners are appropriate in diminishing mobility among service providers, only if the benefits and advantages outweigh the problems. Recent research, albeit in a B2B goods context, supports this view (Gedeon et al., 2009).

The significant finding regarding the relationships between dependence and repurchase intentions indicate that a customer who is dissatisfied overall may intend to repurchase services, if the current provider fulfils needs that may not be obtained in alternate relationships (Drigotas and Rusbult, 1992). Thus, the decision to remain in a given relationship is related to the degree of dependence on that relationship. The significant finding regarding the relationship between calculative commitment and repurchase intentions indicates that considerable inertia exists among dissatisfied customers in the B2B services sector, because of negative emotional attachment caused by cost/benefit reasoning where the costs outweigh the benefits.

A hypothesis regarding firm-level investments that is not supported by the data is the relationship between economic-risk costs and calculative commitment, possibly because 
economic-risk costs affect repurchase intentions directly. This relationship was tested $(\beta=$ $0.22, \mathrm{p}<.001)$ as it made substantive theoretical sense. Business buyers are generally characterised by higher risk and uncertainty than buyers in consumer markets because of consequences to the purchaser as well as to the firm. In the current study, the mean for economic-risk costs (uncertainty costs) is 4.7 on a seven-point scale. The literature offers evidence that buying firms will respond to uncertainty by relying on existing service providers (Heide and Weiss, 1995). Therefore, customer firms that have increased perceptions of uncertainty associated with switching to another service provider would maintain their status quo, and continue to repurchase services, at least until the companies choose to reduce their risk and uncertainty by adopting risk-handling strategies. However, the current study indicated that customer organisations were not very successful in reducing uncertainty by (1) gathering additional information, because they faced considerable evaluation costs (mean $=4.0$ on a seven-point scale) or (2) spreading the risk by using split procurements, because they did not use multiple-sourcing for the service ( $61 \%$ of the sample). The latter finding concurs with the literature, which asserts that a service buyer typically does not share purchases (Rundle-Thiele and Bennett, 2001).

Another hypothesis that is not supported by the data is the relationship between attractiveness of alternative service providers and calculative commitment. One possible explanation is that constraint-based relationships are, in part, a function of a lack of alternative providers, rather than attractiveness of alternatives, which could account for the non-significant relationship between the two constructs (Bansal, Irving and Taylor, 2004). Alternatively, dependence may moderate the relationship between attractiveness of alternative service providers and calculative commitment. Furthermore, our data indicated that unattractiveness of alternative service providers did not affect repurchase intentions directly, which is inconsistent with a recent finding in an industrial goods context (Yen and Horng, 2010). Clearly, more research is needed to investigate the effect of alternative service providers.

\section{Theoretical contribution}

This paper makes several contributions to marketing theory on "why dissatisfied customers stay'. Firstly, the study used a business services context, which is an underresearched area for this research problem. The fastest growth in services marketing is in business markets (Wölfl, 2005), making this an important area of study with significance for marketers, particularly in terms of the development of customer retention. Secondly, the study examined the effects of different types of antecedents (dependence, switching costs, 
interpersonal relationships and alternatives) on calculative commitment that have previously not been examined. By doing so, this current research offers a contribution for service providers to minimise the risk of developing strategies that either overemphasise or underemphasise the significance of certain variables in the development of customers' calculative commitment. Finally, the study included justice components in the current research model that is built on the investment model of the social exchange framework (Rusbult et al., 1998), to explain "unjustified persistence". The investment model has previously not considered equity/justice in the achievement of satisfaction.

\section{Managerial contribution}

Managers should be cautious in employing switching barriers as mechanisms for customer retention, because: (1) investments may impede customer acquisitions, (2) unwanted dependent relations might intensify customer perceptions of being in hostage relationships (Colwell and Hogarth-Scott, 2004) and (3) calculative committed customers might be loyal only while the relationship is instrumentally rewarding (Samuelsen and Sandvik, 1997). Being unable to exit might exacerbate the need to hold a grudge to compensate for a wrong (Bunker and Ball, 2008). The long-term effects of such "hostage" behaviour perceptions probably erode potential enduring relationships (Colwell and Hogarth-Scott, 2004) or fade them (Tuominen and Kettunen, 2003). Indeed, relationships faded for nearly $40 \%$ of the customer firms in this current study.

Although service managers may be unable to prevent such relationships from entering a dissolution phase, they can prevent the ending of customer relationships by handling complaints effectively. An emphasis on achieving satisfaction with complaint handling lessens customers' potential feelings of resentment towards offending service providers (Bunker and Ball, 2008). Thus, whilst dialectical tensions are an inherent part of many relationships and lead to instability and constant change (Montgomery, 1993); service managers can apply restorative actions as a maintenance strategy in deteriorating relationships (Tahtinen and Vaaland, 2006).

However, offending service firms may not be insured against customer defection over the long-term. This is because the gains expected from the complaint-handling process may not totally compensate for the losses which have arisen due to the repeat service failures. Repeat service failures are likely to lead to greater than additive costs compared to a series of single failures (Smith, Bolton and Wagner, 1999). From this point of view, dependence may be 
experienced as one of the costs of participating in a particular relationship (Sabatelli and Shehan, 1993). Consequently, customers may wish to reduce their dependence on the service provider, unless a substantial recovery takes place, where equity and satisfaction are restored to their original levels.

The current research findings also have implications for service firms that attempt to attract dissatisfied customers away from offending firms. The results identify some forces, such as dependence and calculative commitment, which make it particularly difficult to attract prospective switchers - and this translates to increased entry barriers for potential customers. Other barriers may be overcome if service firms' representatives are well trained in reducing the costs associated with learning about, and uncertainty surrounding the performance of, services that are unfamiliar to prospective switchers. Service providers should minimise the work required by potential customers during the switching process, to overcome expressed or experienced concerns and win the prospective switchers from offending firms. This finding is important considering that dissatisfied customers often become involved in inert buying patterns, where they show limited interest toward alternative service providers in the market (Bozzo, 2002).

\section{Limitations and directions for future research}

This research has limitations that restrict the generalisation of its findings and open up directions for future research. The process of psychometric analysis in the current study yielded a two-item scale for calculative commitment, although it was derived from the scale used by Gilliland and Bello (2002). Specifically, Gilliland and Bello (2002) operationalised investments in terms of sunk costs. However, the five dimensions of switching costs in this current study, which when tested with Gilliland and Bello's (2002) measure of calculative commitment, became problematic. While psychometric analysis of two other parts of the model - benefit-loss costs and procedural justice - also yielded two-item scales, they could be considered less of a concern, because they are dimensions of other constructs in the model. Nevertheless, the measurement scales should be subjected to further assessment before drawing conclusions on their construct validity. The structural model should also be validated with another data set to allow empirical generalisations about the population. However, the obtained low value $(<.05)$ of a population-based fit index (i.e. the RMSEA) in the structural model suggests that the model would fit the population covariance matrix, if it were available (Browne and Cudeck, 1993). 
The current research is a novel attempt to understand the phenomenon of "why dissatisfied customers stay" in the B2B services sector, however additional variables should be investigated in future. The B2C services literature contains some evidence that customers who perceive themselves as being in a hostage relationship still indicate cognitive trust in a service provider, which acts as a deterrent to the dissolution of the relationship, regardless of the customers' unfavourable perception of the relationship (Colwell and Hogarth-Scott, 2004). Thus, future research could investigate the role of cognitive trust as a predictive deterrent for relationship dissolution within hostage relationships.

A non-linear relationship exists between dissatisfaction levels and customer responses, thus customers may respond differently at different levels of dissatisfaction. Therefore, future research could investigate whether the model of retention varies between customer firms that are mildly dissatisfied and those that are moderately to highly dissatisfied. Switching barriers may vary across service industries, as could their impact on dependence, calculative commitment and repurchase intentions. Therefore, future research could detect important differences that may exist between various service sectors.

This research showed that the alternative outcomes of a customer either ending or continuing a dissatisfactory relationship not only depend on the switching barriers, but also on the essential nature of the relationship such as dependence or calculative commitment, and has a set a foundation for further research concerning the retention of dissatisfied customers. 


\section{References}

Anderson, J.C. and Gerbing, D.W. (1988), "Structural equation modeling in practice: a review and recommended two-step approach", Psychological Bulletin, Vol. 103 No. 3, pp. 411-423.

Ajzen, I. (1991), "The theory of planned behaviour", Organizational Behavior and Human Decision Processes, Vol. 50 No. 2, pp. 179-211.

Bansal, H.S., Irving, G. and Taylor, S.F. (2004), "A three-component model of customer commitment to service providers", Journal of the Academy of Marketing Science, Vol. 32 No. 3, pp. 234-50.

Becker, H.S. (1960), "Notes on the concept of commitment", American Journal of Sociology, Vol. 66 No. 1, pp. 32-42.

Bennett, R. (2001), A Study of Brand Loyalty in the Business-to-Business Services Sector, PhD thesis, School of Management, The University of Queensland.

Blodgett, J., Hill, D. and Tax, S. (1997), "The effects of distributive, procedural, and interactional justice on postcomplaint behaviour", Journal of Retailing, Vol. 73 No. 2, pp. 185-210.

Bollen, K.A. (1989), Structural Equations with Latent Variables, Wiley, New York.

Bozzo, C. (2002), "Understanding inertia in an industrial context", Journal of Customer Behavior, Vol. 1 No. 3, pp. 335-355.

Browne, M.W. and Cudeck, R. (1993), "Alternate ways of assessing model fit", in Bollen, K.A. and Long, J.S. (Eds.), Testing Structural Equation Models, Sage, Newbury Park, California, pp. 136-162.

Burnham, T.A., Frels, J.K. and Mahajan, V. (2003), "Consumer switching costs: a typology, antecedents, and consequences", Journal of the Academy of Marketing Science, Vol. 31 No. 2, pp. 109-126.

Bunker, M.P. and Ball, D. (2008), "Causes and consequences of grudge-holding in service relationships", Journal of Services Marketing, Vol. 22 No. 1, pp. 37-47.

Campbell, D.T. (1955), "The informant in quantitative research", American Journal of Sociology, Vol. 60 No. 4, pp. 339-342.

Colgate, M. and Norris, M. (2001), "Developing a comprehensive picture of service failure", International Journal of Service Industry Management, Vol. 12 No. 3/4, pp. 215-34.

Colgate, M., Tong, V.T. and Lee C.K. (2007), "Farley JU. Back from the brink: why customers stay", Journal of Service Research, Vol. 9 No. 3, pp. 211-28.

Colwell, S.R. and Hogarth-Scott, S. (2004), "The effect of cognitive trust on hostage relationships", Journal of Services Marketing, Vol. 18 No. 5, pp. 384-394.

de Ruyter, K., Moorman, L. and Lemmink, J. (2001) "Antecedents of commitment and trust in customer-supplier relationships in high technology markets", Industrial Marketing Management, Vol. 30 No. 3, pp. 271-286.

Deutskens, E., de Ruyter, K. and Wetzels, M. (2006), "An assessment of equivalence between online and mail surveys in service research", Journal of Service Research, Vol. 8 No. 4, pp. 346-355.

Drigotas, S.M. and Rusbult, C.E. (1992), "Should I stay or should I go?: A dependence model of breakups", Journal of Personality and Social Psychology, Vol. 62 No. 1, pp. 6287.

Emerson, R. (1962), "Power dependence relations", American Sociological Review, Vol. 27 No. 1, pp. 31-41.

Fornell, C. and Larcker, D. (1981), "Evaluating structural equation models with unobservable variables and measurement error", Journal of Marketing Research, Vol. 18 No. 1, pp. $39-50$. 
Frazier, G.L. (1983), "Interorganizational exchange behavior: a broadened perspective", Journal of Marketing, Vol. 47 No. 4, pp. 68-78.

Fullerton, G. (2003). When does commitment lead to loyalty. Journal of Service Research, Vol. 5 No. 4, pp. 333-344.

Ganesan, S. (1994), "Determinants of long-term orientation in buyer-seller relationships", Journal of Marketing, Vol. 58 No. 2, pp. 1-19.

Ganesh, J., Arnold, M.J. and Reynolds, K.E. (2000), "Understanding the customer base of service providers: an examination of the differences between switchers and stayers", Journal of Marketing, Vol. 64 No. 3, pp. 65-87.

Gedeon, I.M., Fearne, A. and Poole, N. (2009), "The role of inter-personal relationships in the dissolution of business relationships", Journal of Business \& Industrial Marketing, Vol. 24 No. 3/4, pp. 218-226.

Gerbing, D.W. and Anderson, J.C. (1988), “An updated paradigm for scale development incorporating unidimensionality and its assessment", Journal of Marketing Research, Vol. 25 No. 2, pp. 186-192.

Gilliland, D.I. and Bello, D.C. (2002), "Two sides to attitudinal commitment: the effect of calculative and loyalty commitment on enforcement mechanisms in distribution channels", Journal of the Academy of Marketing Science, Vol. 30 No. 1, pp. 24-43.

Goodwin, C. and Ross, I. (1992), "Consumer responses to service failures: influence of procedural and interactional fairness perceptions", Journal of Business Research, Vol. 25 No. 2, pp. 149-163.

Gounaris, S.P. (2005), "Trust and commitment influences on customer retention: insights from business-to-business services", Journal of Business Research, Vol. 58 No. 2, pp. 126140.

Heide, J.B. and Weiss, A.M. (1995), "Vendor consideration and switching behavior for buyers in high-technology markets", Journal of Marketing, Vol. 59 No. 3, pp. 30-43.

Hellier, P., Geursen, G., Carr, R. and Rickard, J. (2003) "Customer repurchase intention: a general structural equation model", European Journal of Marketing, Vol. 37 No. 11/12, pp. 1762-1800.

Hoffman, K.D. and Kelley, S.W. (2000) "Perceived justice needs and recovery evaluation: a contingency approach", European Journal of Marketing, Vol. 34 No. 3/4, pp. 418-432.

Homburg, C. and Furst, A. (2005), "How organizational complaint handling drives customer loyalty: an analysis of the mechanistic and the organic approach", Journal of Marketing, Vol. 69 No. 3, pp. 95-114.

Huang, L., Cheng, T. and Farn, C. (2007), "The mediating effect of commitment on customer loyalty towards e-brokerages: an enhanced investment model", Total Quality Management, Vol. 18 No. 7, pp. 751-770.

Iacobucci, D. and Ostrom, A.L. (1996), "Commercial and interpersonal relationships: using the structure of interpersonal relationships to understand individual-to-individual, individual-to-firm, and firm-to-firm relationships in commerce", International Journal of Research in Marketing, Vol. 13 No. 1, pp. 53-72.

Johnson, M.P. (1991), "Commitment to personal relationships", in: Jones, W.H. and Perlman, D.W. (Eds.), Advances in Personal Relationships, Vol. 3, Jessica Kingsley, London, pp. 117-143.

Jones, M.A., Mothersbaugh, D.L. and Beatty, S.E. (2000), "Switching barriers and repurchase intentions in services", Journal of Retailing, Vol. 76 No. 2, pp. 259-274.

Jones, M.A., Mothersbaugh, D.L. and Beatty, S.E. (2002), "Why customers stay: measuring the underlying dimensions of services switching costs and managing their differential strategic outcomes", Journal of Business Research, Vol. 55 No. 6, pp. 441-450. 
Jones, M.A., Reynolds, K.E., Mothersgbaugh, D.L. and Beatty, S.E. (2007), “The positive and negative effects of switching costs on relational outcomes", Journal of Service Research, Vol. 9 No. 4, pp. 335-355.

Joshi, A.W. and Arnold, S.J. (1998), "How relational norms affect compliance in industrial buying", Journal of Business Research, Vol. 41 No. 2, pp. 105-114.

Keaveney, S. (1995), "Consumer switching behavior in service industries: an exploratory study", Journal of Marketing, Vol. 59 No. 2, pp. 71-82.

Kohli, A. (1989), "Determinants of influence in organizational buying: a contingency approach", Journal of Marketing, Vol. 53 No. 3, pp. 50-65.

Lam, S.Y., Shankar, V., Erramilli, M.K. and Murthy, B. (2004), "Customer value, satisfaction, loyalty, and switching costs: an illustration from a business-to-business service context", Journal of the Academy of Marketing Science, Vol. 32 No. 3, pp. 293-311.

Liu, A.H. (2006), "Customer value and switching costs in business services: developing exit barriers through strategic value management", Journal of Business \& Industrial Marketing, Vol. 21 No. 1, pp. 30-37.

Liu, A.H., Leach, M.P. and Bernhardt, K.L. (2005), "Examining customer value perceptions of organizational buyers when sourcing from multiple vendors", Journal of Business Research, Vol. 58 No. 5, pp. 559-568.

Maxham, J.G. and Netemeyer, R.G. (2002), "A longitudinal study of customer evaluations of multiple service failures and recoveries", Journal of Marketing, Vol. 66 No. 4, pp. 57-71.

Montgomery, J.D. (1998), “Toward a role-theoretic conception of embeddedness", American Journal of Sociology, Vol. 104 No. 1, pp. 92-125.

Moorman, C., Zaltman, G. and Deshpande, R. (1992), "Relationships between providers and users of market research: the dynamics of trust within and between organizations", Journal of Marketing Research, Vol. 29, No. 3, pp. 314-328.

Patterson, P.G. (2004), "A contingency model of behavioural intentions in a services context", European Journal of Marketing, Vol. 38 No. 9/10, pp. 1304-1315.

Patterson, P.G., Johnson, L.W. and Spreng, R.A. (1997), "Modeling the determinants of customer satisfaction for B2B professional services", Journal of the Academy of Marketing Science, Vol. 25 No. 1, pp. 4-17.

Patterson, P.G. and Smith, T. (2003), "A cross cultural study of switching barriers and propensity to stay with service providers", Journal of Retailing, Vol. 79 No. 2, pp. 107-120.

Pennings, J.M. (1979), "Coordination between strategically interdependent organizations", in Nystrom, P. and Starbuck, W. (eds.), Handbook of Organizational Design, Elsevier, Amsterdam.

Phillips, L.W. (1981), "Assessing measurement error in key informant reports: a methodological note on organizational analysis in marketing", Journal of Marketing Research, Vol. 18 No. 4, pp. 395-415.

Ping, R.A. (1997), "Voice in business-to-business relationships: cost-of-exit and demographic antecedents", Journal of Retailing, Vol. 73 No. 2, pp. 261-281.

Ping, R.A. (1999), "Unexplored antecedents of exiting in a marketing channel", Journal of Retailing, Vol 75 No 2, pp. 218-241.

Prasongsukarn, K. (2005), The Impact of Cultural Value Orientation on Customer Perceptions of Post-Recovery Service Satisfaction in an Eastern Context, PhD thesis, School of Marketing, University of New South Wales.

Price, L.L. and Arnould, E.J. (1999), "Commercial friendships: service provider-client relationships in context", Journal of Marketing, Vol. 63 No. 4, pp. 38-56. 
Rauyruen, P. and Miller, K.E. (2007), "Relationship quality as a predictor of B2B customer loyalty", Journal of Business Research, Vol. 60 No. 1, pp. 21-31.

Reichheld, F.W. and Sasser, W.E. (1990), "Zero defections: quality comes to services", Harvard Business Review, Vol. 68 No. 5, pp. 105-110.

Rokkan, A.I., Heide, J.B. and Wathne, K.H. (2003), "Specific investments in marketing relationships: expropriation and bonding effects", Journal of Marketing Research, Vol. 40 No. 2, pp. 210-224.

Roos, I., Edvardsson, B. and Gustafsson, A. (2004), "Customer switching patterns in competitive and non-competitive service industries", Journal of Service Research, Vol. 6 No. 3, pp. 256-271.

Rundle-Thiele, S. and Bennett, R. (2001), "A brand for all seasons? a discussion of brand loyalty approaches and their applicability for different markets", Journal of Product \& Brand Management, Vol. 10 No. 1, pp. 25-37.

Rusbult, C.E., Martz, J.M. and Agnew, C.R. (1998), "The investment model scale: measuring commitment level, satisfaction level, quality of alternatives, and investment size", Personal Relationships, Vol. 5, pp. 357-391.

Rusbult, C.E., Zembrodt, I.M. and Gunn, L.K. (1982), "Exit, voice, loyalty, and neglect: responses to dissatisfaction in romantic involvement", Journal of Personality and Social Psychology, Vol 43 No 6, pp. 1230-1242.

Sabatelli, R.M. and Shehan, C. (1993), "Exchange and resource theories", in Boss, P., Doherty, W., LaRossa, R., Schuum, W. and Steinmetz, S. (eds.), Sourcebook of Family Theories and Methods, Plenum Press, New York.

Samuelsen, B. and Sandvik, K. (1997), "The concept of customer loyalty" in Arnott, D. and Bridgewater, S. (Eds.), 26th EMAC Conference Proceedings. Marketing: Progress, Prospects and Perspectives, Warwick Business School, University of Warwick, Coventry, Vol. 3, pp. 1122-1140.

Smith, A., Bolton, R. and Wagner, J. (1999), "A model of customer satisfaction with service encounters involving failure and recovery", Journal of Marketing Research, Vol 36 No 3, pp. 356-372.

Seabright, M.A., Levinthal, D.A. and Fichman, M. (1992), "Role of individual attachments in the dissolution of interorganizational relationships", Academy of Management Journal, Vol. 35, No. 1, pp. 122-160.

Sweeney, J. and Swait, J. (2008), "The effects of brand credibility on customer loyalty", Journal of Retailing and Consumer Services, Vol. 15 No. 3, pp. 179-193.

Sweeney, J. and Webb, D.A. (2007), "How functional, psychological, and social relationship benefits influence individual and firm commitment to the relationship", Journal of Business \& Industrial Marketing, Vol. 22 No. 7, pp. 474-488.

Tahtinen, J. and Vaaland, T. (2006), "Business relationships facing the end: why restore them?", "Journal of Business \& Industrial Marketing" Vol. 21 No. 1, pp. 14-23.

Tax, S.S., Brown, S.W. and Chandrashekaran, M. (1998), "Customer evaluations of service complaint experiences: implications for relationship marketing", Journal of Marketing, Vol. 62 No. 2, pp. 60-76.

Tuominen, P. and Kettunen, U. (2003), "To fade or not to fade? That is the question in customer relationships, too", Managing Service Quality, Vol. 13 No. 2, pp. 112-123.

Venetis, K.A. and Ghauri, P.N. (2004), "Service quality and customer retention: building longterm relationships", European Journal of Marketing, Vol. 38 No. 11/12, pp. 15771598 .

Wathne, K.H., Biong, H. and Heide, J.B. (2001), "Choice of supplier in embedded markets: relationship and marketing program effects", Journal of Marketing, Vol. 65 No. 2, pp. 54-66. 
Wetzels, M., de Ruyter, K. and van Birgelen, M. (1998), "Marketing service relationships: the role of commitment", Journal of Business \& Industrial Marketing, Vol. 13 No. 3/4, pp. 406-423.

Wilson, D.T. (1995), "An integrated model of buyer-seller relationships", Journal of the Academy of Marketing Science, Vol. 23 No. 4, pp. 335-345.

Wilson, D.T. and Mummalaneni, V. (1986), "Bonding and commitment in supplier relationships: a preliminary conceptualization”, Industrial Marketing and Purchasing, Vol. 1 No. 3, pp. 44-58.

Wölfl, A. (2005), "The service economy in OECD countries", STI Working Paper 2005/3, Statistical Analysis of Science, Technology and Industry, France.

Yanamandram, V. and White, L. (in press), Why do some business relationships persist despite dissatisfaction? A social exchange review, Asia Pacific Management Review.

Yanamandram, V. K. and White, L. (2006), "Switching barriers in business-to-business services: a qualitative study. Journal of Service Management, Vol 17 No 2, pp. 158192

Yen, Y.Z. and Horng, D.J. (2010), "Effects of satisfaction, trust and alternative attractiveness on switching intentions in industrial customers", International Journal of Management and Enterprise Development, Vol. 8 No. 1, pp. 82-101. 
Table 1. Confirmatory factor analysis properties

\begin{tabular}{|c|c|c|c|c|}
\hline Factor and Item & S.F.L $\mathbf{L}^{\mathrm{a}}$ & C.R. ${ }^{\mathbf{b}}$ & V.E. ${ }^{\mathbf{c}}$ & Source of scale item \\
\hline Distributive Justice & & 0.844 & 0.643 & Burnham et al. (2003) \\
\hline In resolving our complaint(s), the service provider gave us exactly what we needed. & .822 & & & Tax et al. (1998) \\
\hline We got what we deserved from the complaint(s). & .782 & & & Tax et al. (1998) \\
\hline The compensation we received from our service provider, in response to our complaint(s), was fair. & .802 & & & Tax et al. (1998) \\
\hline Procedural Justice & & 0.869 & 0.77 & \\
\hline The service provider responded quickly to our complaint(s). & .799 & & & Blodgett at al. (1997) \\
\hline The company's complaint(s) handling procedure was fair. & .949 & & & Homburg and Furst (2005) \\
\hline Interactional Justice & & 0.91 & 0.717 & \\
\hline $\begin{array}{l}\text { We felt treated politely during interactions with the employee(s) of the service provider when } \\
\text { handling complaint(s). }\end{array}$ & .818 & & & Homburg and Furst (2005) \\
\hline The employee(s) of the service provider were very keen to solve our problem(s). & .901 & & & Homburg and Furst (2005) \\
\hline The behaviour of the employee(s) of the service provider during complaint(s) handling was fair. & .875 & & & Homburg and Furst (2005) \\
\hline Benefit-Loss Costs & & 0.804 & 0.673 & \\
\hline $\begin{array}{l}\text { By continuing to use the same service provider, we receive certain benefits that we would not } \\
\text { receive if we switched to a new one. }\end{array}$ & .820 & & & Jones et al. (2002) \\
\hline Our service provider provides us with particular privileges we would not receive elsewhere. & .820 & & & Jones et al. (2002) \\
\hline Switching to a new service provider will probably result in unexpected hassle. & .794 & & & Burnham et al. (2003) \\
\hline We worry that the service offered by other service providers won't work as well as expected. & .879 & & & Burnham et al. (2003) \\
\hline We are not sure what the level of service would be if we switched to a new service provider. & .833 & & & Jones et al. (2002) \\
\hline Evaluation Costs & & 0.893 & 0.736 & \\
\hline We cannot afford the time to obtain the information to fully evaluate other service providers. & .800 & & & Burnham et al. (2003) \\
\hline $\begin{array}{l}\text { Comparing our current service provider with potential service providers takes too much effort, even } \\
\text { when we have the information. }\end{array}$ & .924 & & & Burnham et al. (2003) \\
\hline Analysing the information on alternative service providers takes too much time. & .845 & & & New item \\
\hline Learning Costs & & 0.92 & 0.794 & \\
\hline Learning to use the features offered by a new service provider would take time. & .912 & & & Burnham et al. (2003) \\
\hline $\begin{array}{l}\text { If we switched from our current service provider, we would have to learn the new service } \\
\text { provider's systems. }\end{array}$ & .912 & & & Jones et al. (2002) \\
\hline Getting used to how a new service provider works would be difficult. & .847 & & & Burnham et al. (2003) \\
\hline Sunk costs & & 0.897 & 0.813 & \\
\hline $\begin{array}{l}\text { We have put a considerable amount of time into building and maintaining the relationship with our } \\
\text { current service provider. }\end{array}$ & .849 & & & Jones et al. (2002) \\
\hline A lot of effort has gone into building and maintaining the relationship with the current service & .951 & & & Ping (1993) \\
\hline
\end{tabular}




\begin{tabular}{|c|c|c|c|c|}
\hline provider. & & & & \\
\hline Interpersonal Relationships & & 0.926 & 0.807 & \\
\hline I have personally developed a friendship with at least one salesperson of the service provider. & .848 & & & Jones et al. (2002) \\
\hline At least one salesperson of the service provider is familiar with me personally. & .897 & & & Jones et al. (2002) \\
\hline I have personally developed a good rapport with at least one sales person of the service provider. & .947 & & & New item \\
\hline Attractiveness of Alternatives & & 0.906 & 0.764 & \\
\hline If we needed to change service providers, there are other good service providers to choose from. & .855 & & & Jones et al. (2002) \\
\hline $\begin{array}{l}\text { Compared to this service provider, there are other service providers with which we would probably } \\
\text { be more satisfied. }\end{array}$ & .913 & & & Jones et al. (2002) \\
\hline Satisfaction with Complaint-Handling & & 0.935 & 0.828 & \\
\hline Overall, how do you feel about your service provider's handling of the problem(s)? & & & & \\
\hline Very Dissatisfied $* * * * * * *$ Very Satisfied & .866 & & & Prasongsukarn (2005) \\
\hline Did a Poor Job $\quad * * * * * * *$ Did a Good Job & .928 & & & Prasongsukarn (2005) \\
\hline Unhappy $\quad * * * * * * *$ Happy & .933 & & & Prasongsukarn (2005) \\
\hline Dependence & & 0.921 & 0.796 & \\
\hline This service provider is crucial to our future performance. & .881 & & & Ganesan (1994) \\
\hline This service provider is important to our business. & .880 & & & Ganesan (1994) \\
\hline Calculative Commitment & & 0.876 & 0.781 & \\
\hline $\begin{array}{l}\text { Even if we wanted to shift business away from this service provider, we couldn't because our losses } \\
\text { would be significant. }\end{array}$ & .804 & & & Gilliland and Bello (2002) \\
\hline $\begin{array}{l}\text { We need to keep working with this service provider since leaving would create hardship for our } \\
\text { business. }\end{array}$ & .957 & & & Gilliland and Bello (2002) \\
\hline Repurchase Intentions & & 0.892 & 0.735 & \\
\hline Even though problem(s) occurred, we will still purchase a service from our current service provider. & .763 & & & New item \\
\hline We are reluctant to discontinue our current service provider as a source of supply. & .879 & & & New item \\
\hline We intend to continue purchasing services from our current service provider. & .922 & & & New item \\
\hline
\end{tabular}

Note: All are statistically significant, $\mathrm{p}<0.001 ; \mathrm{n}=376$

All items include seven-point Likert-type scale responses, with the exception of satisfaction with complaint handling

${ }^{\text {a }}$ Standardized factor loadings

b Construct reliability

c Variance extracted 
Table 2. Bivariate Correlations, Means and Standard Deviations (SD)

\begin{tabular}{|c|c|c|c|c|c|c|c|c|c|c|c|c|c|c|c|}
\hline & Variable & 1 & 2 & 3 & 4 & 5 & 6 & 7 & 8 & 9 & 10 & 11 & 12 & 13 & 14 \\
\hline 1 & Distributive_Justice & 1.000 & & & & & & & & & & & & & \\
\hline 2 & Procedural_Justice & $.633 * *$ & 1.000 & & & & & & & & & & & & \\
\hline 3 & Interactional_Justice & $.477 * *$ & $.661 * *$ & 1.000 & & & & & & & & & & & \\
\hline 4 & BenefitLoss_Costs & $.290 * *$ & $.175^{* *}$ & $.251 * *$ & 1.000 & & & & & & & & & & \\
\hline 5 & EconomicRisk_Costs & -.033 & .025 & $.115^{*}$ & $.279 * *$ & 1.000 & & & & & & & & & \\
\hline 6 & Evaluation_Costs & .015 & .044 & .048 & $.201 * *$ & $.506 * *$ & 1.000 & & & & & & & & \\
\hline 7 & Learning_Costs & $.155^{* *}$ & $.132 * *$ & $.127 * *$ & $.211 * *$ & $.481 * *$ & $.472 * *$ & 1.000 & & & & & & & \\
\hline 8 & Sunk_Costs & $.192 * *$ & $.163 * *$ & $.228 *$ & $.265 * *$ & $.220 * *$ & $.132 * *$ & $.304 * *$ & 1.000 & & & & & & \\
\hline 9 & Interpersonal_Relation & $.284 * *$ & $.230 * *$ & $.247 * *$ & $.221 * *$ & .038 & .060 & $.246 * *$ & $.466 * *$ & 1.000 & & & & & \\
\hline 10 & Alternative_Attr & -.059 & .030 & $.109 *$ & -.055 & .035 & -.005 & -.007 & $.286^{* * *}$ & .024 & 1.000 & & & & \\
\hline 11 & Complaint_Satisfaction & $.636^{* * *}$ & $.651 * *$ & $.599 * *$ & $.167 * *$ & .001 & -.010 & $.127 * *$ & $.158 * *$ & $.266 * *$ & -.060 & 1.000 & & & \\
\hline 12 & Dependence & .061 & .057 & .059 & $.335 * *$ & $.219 * *$ & $.114^{*}$ & $.196 * *$ & $.374 * *$ & $.229 * *$ & .022 & .017 & 1.000 & & \\
\hline 13 & Calculative_Commit & $.134 * *$ & .041 & .057 & $.347 * *$ & $.248 * *$ & $.300 * *$ & $.380 * *$ & $.372 * *$ & $.168^{* *}$ & -.026 & .005 & $.446 * *$ & 1.000 & \\
\hline 14 & Repurchase_Intentions & $.250 * *$ & $.282 * *$ & $.293 * *$ & $.443 * *$ & $.353 * *$ & $.274 * *$ & $.334 * *$ & $.321 * *$ & $.178 * *$ & -.033 & $.212 * *$ & $.366 * *$ & $.358 * *$ & 1.000 \\
\hline & Mean & 2.871 & 3.173 & 3.595 & 3.544 & 4.674 & 4.043 & 4.12 & 4.275 & 3.562 & 4.664 & 3.196 & 4.194 & 3.465 & 4.046 \\
\hline & SD & 1.252 & 1.405 & 1.327 & 1.535 & 1.383 & 1.419 & 1.422 & 1.452 & 1.691 & 1.254 & 1.313 & 1.586 & 1.51 & 1.284 \\
\hline
\end{tabular}

Key to Variables: Distributive_Justice = Distributive Justice; Procedural_Justice = Procedural Justice; Interactional_Justice $=$ Interactional Justice; BenefitLoss_Costs = Benefit-Loss Costs; EconomicRisk Costs = Economic-Risk Costs; Evaluation Costs = Evaluation Costs; Learning Costs = Learning Costs; Sunk Costs = Sunk Costs; Interpersonal_Relation = Interpersonal Relationships; Alternative_Attr = Attractiveness of Alternatives; Complaint_Satisfaction = Satisfaction with Complaint-Handling; Dependence $=$ Dependence; Calculative_Commit $=$ Calculative Commitment; Repurchase_Intentions $=$ Repurchase intentions .

* Correlation significant at $\mathrm{p}<.05$ (one-tailed test); **Correlation significant at $\mathrm{p}<.01$ (one-tailed test) 
Table 3. Structural parameter estimates

\begin{tabular}{|c|c|c|c|c|}
\hline Hypothesized path & B & $\mathbf{t}$ & $\mathbf{p}$ & Comments \\
\hline $\mathrm{H}_{1 \mathrm{a}}$ : Distributive Justice $\rightarrow$ Satisfaction with Complaint Handling & .44 & 6.26 & .000 & Supported \\
\hline $\mathrm{H}_{1 \mathrm{~b}}$ : Procedural Justice $\rightarrow$ Satisfaction with Complaint Handling & .21 & 2.51 & .012 & Supported \\
\hline $\mathrm{H}_{1 \mathrm{c}}$ : Interactional Justice $\rightarrow$ Satisfaction with Complaint Handling & .24 & 3.88 & .000 & Supported \\
\hline $\mathrm{H}_{2}:$ Dependence $\rightarrow$ Calculative Commitment & .30 & 5.42 & .000 & Supported \\
\hline $\mathrm{H}_{3 \mathrm{a}}:$ Benefit-Loss Costs $\rightarrow$ Calculative Commitment & .18 & 3.02 & .003 & Supported \\
\hline $\mathrm{H}_{3 \mathrm{~b}}:$ Economic-Risk Costs $\rightarrow$ Calculative Commitment & -.08 & -1.19 & .235 & Not supported \\
\hline $\mathrm{H}_{3 \mathrm{c}}:$ Evaluation Costs $\rightarrow$ Calculative Commitment & .15 & 2.48 & .013 & Supported \\
\hline $\mathrm{H}_{3 \mathrm{~d}}$ : Learning Costs $\rightarrow$ Calculative Commitment & .24 & 3.88 & .000 & Supported \\
\hline $\mathrm{H}_{3 \mathrm{e}}:$ Sunk Costs $\rightarrow$ Calculative Commitment & .25 & 3.73 & .000 & Supported \\
\hline $\mathrm{H}_{4}:$ Interpersonal Relationships $\rightarrow$ Calculative Commitment & -.14 & -.2 .63 & .009 & Supported \\
\hline $\mathrm{H}_{5}$ : Attractiveness of Alternative Service Providers $\rightarrow$ Calculative Commitment & -.09 & -1.76 & .079 & Not supported \\
\hline $\mathrm{H}_{6}:$ Satisfaction with Complaint Handling $\rightarrow$ Repurchase intentions & .17 & 3.52 & .000 & Supported \\
\hline $\mathrm{H}_{7}:$ Dependence $\rightarrow$ Repurchase Intentions & .16 & 2.80 & .005 & Supported \\
\hline $\mathrm{H}_{8}:$ Calculative Commitment $\rightarrow$ Repurchase Intentions & .20 & 3.41 & .000 & Supported \\
\hline $\mathrm{H}_{9}:$ Benefit-Loss Costs $\rightarrow$ Repurchase Intentions & .34 & 5.33 & .000 & Supported \\
\hline
\end{tabular}

